\title{
Shiraliyeva N.A.•
}

DOI: 10.25108/2304-1730-1749.iolr.2017.53.161-172

\section{Paradoxes of European Court on Human Rights}

Abstract: European Court on Human Rights is not a higher court in relation to the judicial system of a State party of the Convention, and therefore it is not entitled to revoke a decision rendered by public authority or national court. The Court does not give instructions to a lawmaker, does not exercise a control of national legislation or judicial practice. It has no right to give the orders on adoption the measures that have legal consequences.

Keywords: European Court on Human Rights; judgement; jurisdiction; case of Ilgar Mammadov.

According to part 2 of Article 148 of the Constitution of Azerbaijan Republic, international treaties, wherein Azerbaijan Republic is a party, are an integral part of legislative system of Azerbaijan Republic.

According to Article 151 of the Constitution of Azerbaijan Republic, whenever there is disagreement between normative-legal acts in legislative system of the Republic of Azerbaijan (except Constitution of the Republic of Azerbaijan and acts accepted by way of referendum) and international agreements wherein the Republic of Azerbaijan is one of the parties, provisions of international agreements shall dominate [2].

On 25 January 2001 Azerbaijan Republic joined to European Convention on Protection of Human Rights and Fundamental Freedoms and its Protocols and thereby has recognised the jurisdiction of European Court on Human Rights on interpretation and application of the Convention and its Protocols.

\footnotetext{
- Shiraliyeva Narmina Azer gyzy - a member of International Organization for Legal Researches, the Western University (Azerbaijan). E-mail: mopi_sid@yahoo.com
} 
With a Decree of the President of Azerbaijan Republic on 27 December 2011 it was adopted "National Program for Action to Raise Effectiveness of the Protection of Human Rights and Freedoms in the Republic of Azerbaijan" that aimed to providing the sustainable measures directed to raise effectiveness of the protection of human rights and freedoms, developing legal culture in society, improving law and regulations and human rights system [3].

In legislation of Azerbaijan Republic has been included the norms, which provide review of judicial acts, when European Court on Human Rights finds the violation of the provisions of Convention "On Protection of Rights and Fundamental Freedom of Man" in the courts of Azerbaijan Republic.

According to jurisdiction, European Court is not a higher court in relation to the judicial system of a State party of the Convention, and therefore it is not entitled to revoke a decision rendered by public authority or national court. The Court does not give instructions to a lawmaker, does not exercise a control of national legislation or judicial practice. It has no right to give the orders on adoption the measures that have legal consequences. Court examines only specific complaints in order to establish whether the requirements of Convention were violated and it has right to award "just satisfactions" in form of financial compensation of pecuniary and non-pecuniary damage, and also the reimbursement to the applicant the costs and expenses.

According to the Statute of Council of Europe, non-performance of the Court's judgements by States-members of Council of Europe may entail to suspension of membership, and eventually, in compliance with decision of the Committee of Ministers - to expelling of a State from the Council of Europe.

According to Article 46 of Convention, the final judgment of the Court shall be transmitted to the Committee of Ministers, which shall supervise not only its execution but also for that how a State party revises obvious discrepancies of the norms of its domestic law or positions of judicial practice with standards of 
Council of Europe. Legally, a decision rendered by the Court is binding only on a respondent State on the case, however it is often a significancy of the Court's decisions are beyond the national borders, influencing on law and judicial practice and other States parties of the Convention.

The competence of European Court on Human Rights includes:

- to examine an individual and inter-state complaints that submitted in European Court on Human Rights against one of few State parties of Council of Europe or against European Union;

- to recognise the fact of violation of any applicant's right;

- to award just satisfaction of an applicant;

- to interpret the Convention on Protection of Human Rights and Fundamental Freedoms;

- to establish a fact that any violation has a mass character in a some state due to systematic problem, and in this connection to suggest this state to undertake the measures on correction on this lack;

- to consider an inquiry of the Committee of Ministers of Council of Europe on issue whether a respondent State violated its commitments on execution of judgements (decisions) of European Court on Human Rights;

- to interpret previously made judgements on an inquiry of the Committee of Ministers of Council of Europe;

- to make advisory opinions on interpretation of the Convention on Protection of Human Rights and Fundamental Freedoms, on the matters not associated with examination of the cases [4].

On results of complaint's examination the European Court makes the following main decisions:

- on inadmissibility addressed to an applicant that issued in form of a letter;

- on inadmissibility or admissibility of a complaint in form of separate motivated document; 
- judgement on a case, in which it may recognise a violation of human rights.

In light of above said it seems necessity to consider an issue that exaggerated in last time on, ostensibly, non-performance by Azerbaijan of the decision of European Court no. 15172/13 of 22 May 2014 in respect of Ilgar Mammadov. In this connection, this is a first time in history of the Court when has been initiated the procedure of Article 46.4 of European Convention that says "if the Committee of Ministers considers that a High Contracting Party refuses to abide by a final judgment in a case to which it is a party, it may, after serving formal notice on that Party and by decision adopted by a majority vote of two thirds of the representatives entitled to sit on the committee, refer to the Court the question whether that Party has failed to fulfill its obligation under paragraph1" [1].

Azerbaijan is charged in refusal to execute the Court's decision on immediate release of Ilgar Mammadov from custody.

Meanwhile, the operative part of European Court's decision on the case no. 15172/13 says: "the court, unanimously:

1. Declares the complaints under Article $5 \S \S 1,3$ and 4, Article $6 \S 2$ and Articles 13, 14 and 18 of the Convention admissible and the remainder of the application inadmissible;

2. Holds that there has been a violation of Article $5 \S 1$ (c) of the Convention;

3. Holds that there is no need to examine separately the complaint under Article $5 \S 3$ of the Convention;

4. Holds that there has been a violation of Article $5 \S 4$ of the Convention;

5. Holds that there has been a violation of Article $6 \S 2$ of the Convention;

6. Holds that there is no need to examine the complaints under Articles 13 and 14 of the Convention;

7. Holds that there has been a violation of Article 18 of the Convention taken in conjunction with Article 5 of the Convention;

8. Holds 
(a) that the respondent State is to pay the applicant, within three months from the date on which the judgment becomes final in accordance with Article $44 \S 2$ of the Convention, the following amounts, to be converted into New Azerbaijani manats at the rate applicable at the date of settlement:

(i) EUR 20,000 (twenty thousand euros), plus any tax that may be chargeable, in respect of non-pecuniary damage;

(ii) EUR 2,000 (two thousand euros), plus any tax that may be chargeable to the applicant, in respect of costs and expenses;

(b) that from the expiry of the above-mentioned three months until settlement simple interest shall be payable on the above amounts at a rate equal to the marginal lending rate of the European Central Bank during the default period plus three percentage points;

9. Dismisses the remainder of the applicant's claim for just satisfaction.

Done in English, and notified in writing on 22 May 2014, pursuant to Rule 77 $\S \S 2$ and 3 of the Rules of Court.

$\begin{array}{ll}\text { Søren Nielsen } & \text { Isabelle Berro-Lefèvre } \\ \text { Registrar } & \text { President" [5]. }\end{array}$

As it seen, the Court's judgement says nothing and cannot say about releasing of Ilgar Mammadov from the custody as this issue is not in competence of the Court.

\section{References}

1. Evropeyskaya konventsiya po pravam cheloveka [European Convention on Human Rights]. Available at: www.echr.coe.int/Documents/Convention_RUS.pdf

2. Konstitutsiya Azerbaijanskoy Respubliki [Constitution of Azerbaijan Republic]. S dopolneniyami, po sostoyaniyu na 26.09.2016 [with supplements, as for 29.09.2016]. Available at: http://ru.president.az/azerbaijan/constitution 
3. Rasporyazhenie Prezidenta Azerbaijanskoy Respubliki ob utverzhdenii "Natsional'noy programmy deystviyi po povysheniyu effektivnosti zaschity prav i svobod cheloveka v Azerbaijanskoy Respublike" [Decree of the President of Azerbaijan Republic "National Program for Action to Raise Effectiveness of the Protection of Human Rights and Freedoms in the Republic of Azerbaijan"] of 27 December 2011. Available at: http://ru.president.az/articles/4089

4. Reglament Evropeyskogo suda po pravam cheloveka 2016 g. [Rules of European Court on Human Rights of 2016]. Available at: https://roseurosud.org/ podacha-zhalob-v-espch/ reglament-evropejskogo-suda-po-pravam-cheloveka

5. Reshenie Evropeyskogo suda po pravam cheloveka po delu no. 15172/13 Ilgar Mamedov v Azerbaijan [Judgement of European Court on Human Rights on case no. 15172/13 Ilgar Mammadov $v$ Azerbaijan]. Available at: https://hudoc.echr.coe.int/eng\#\{"itemid":["001-144124"]\}. 